\title{
Julien Cuny. « Retour sur le pied en ronde-bosse achéménide de Suse : de la chaussure à boutons perse à la statue du palais de Darius »
}

\section{Rémy Boucharlat}

\author{
(2) OpenEdition \\ Journals \\ Édition électronique \\ URL : http://journals.openedition.org/abstractairanica/51241 \\ DOI : 10.4000/abstractairanica. 51241 \\ ISBN : 1961-960X \\ ISSN : 1961-960X \\ Éditeur : \\ CNRS (UMR 7528 Mondes iraniens et indiens), Éditions de l'IFRI
}

Référence électronique

Rémy Boucharlat, « Julien Cuny. «Retour sur le pied en ronde-bosse achéménide de Suse : de la chaussure à boutons perse à la statue du palais de Darius » », Abstracta Iranica [En ligne], Volume 40-41 | 2019, document 101, mis en ligne le 30 décembre 2019, consulté le 27 avril 2021. URL : http:// journals.openedition.org/abstractairanica/51241 ; DOI : https://doi.org/10.4000/abstractairanica. 51241

Ce document a été généré automatiquement le 27 avril 2021.

Tous droits réservés 


\title{
Julien Cuny. « Retour sur le pied en ronde-bosse achéménide de Suse : de la chaussure à boutons perse à la statue du palais de Darius »
}

\author{
Rémy Boucharlat
}

\section{RÉFÉRENCE}

Julien Cuny. « Retour sur le pied en ronde-bosse achéménide de Suse : de la chaussure à boutons perse à la statue du palais de Darius » in Claire Hardy-Guilbert, Hélène Renel, Axelle Rougeulle, Eric Vallet (éds.). Sur les chemins d'Onagre : Histoire et archéologie orientales : Hommage à Monik Kervran. Oxford: Archaeopress Archaeology, 2018, p. $41-48$

1 L'A. revient sur un fragment de pied chaussé en ronde bosse, l'une des cinq pièces seulement de la statuaire achéménide de Suse, en plus de la statue de Darius. Ce fragment sculpté ne peut appartenir à une statue totalement semblable à cette dernière, qui est accolée à un pilier dorsal y compris par les pieds, car le pied fragmentaire est dégagé de tous les côtés. À noter de plus qu'il appartient à une statue plus grande que la célèbre représentation de Darius. L'A. s'intéresse par ailleurs à la provenance de ce fragment et des autres qui n'est pas précisée par le fouilleur, R. de Mecquenem. En confrontant les années de découvertes, en 1913 puis après 1922, et les secteurs fouillés au cours de chaque saison, il fait l'hypothèse qu'une (ou deux) statues, royales ou non, prenaient place ailleurs qu'à la Porte de Darius, peut-être à la porte orientale de la Résidence, devant laquelle subsistent deux radiers de fondations. 


\section{AUTEURS}

RÉMY BOUCHARLAT

UMR 5133 CNRS-Université de Lyon 